$-2$ ע
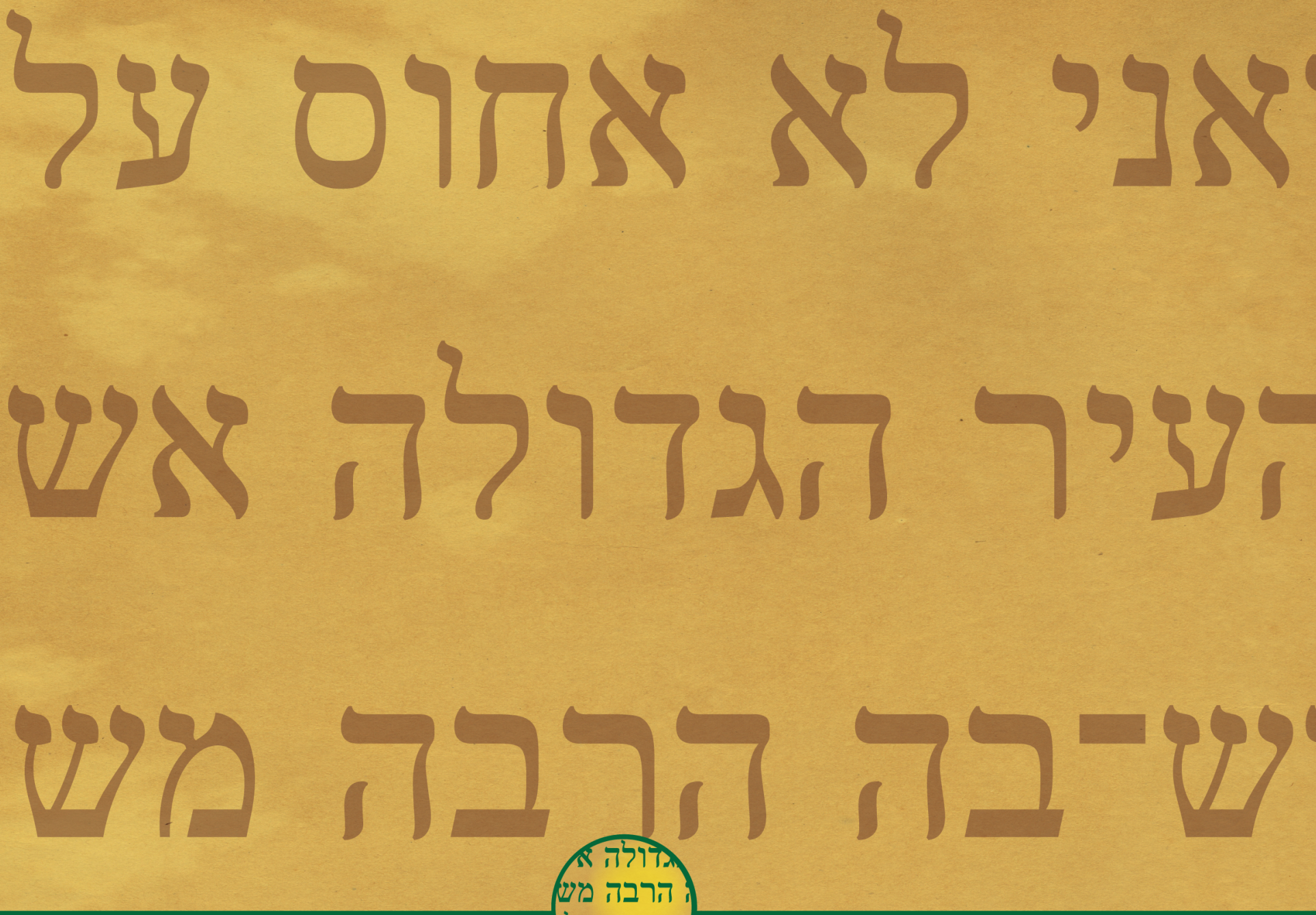

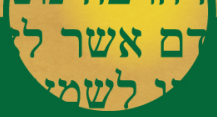

Journal of

HEBREW SCRIPTURES

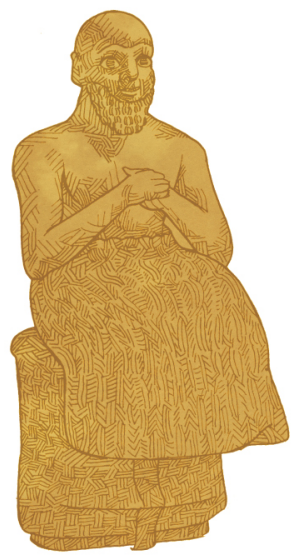

V OL UME 2I R E VIEW I

W I L L I A M S. M O R R O W

Ancient Near Eastern Treaty Traditions and Biblical Covenants: Recent Surveys 


\title{
ANCIENT NEAR EASTERN TREATY TRADITIONS AND BIBLICAL COVENANTS: RECENT SURVEYS
}

\author{
WILLIAM S. MORROW \\ QUEEN'S UNIVERSITY
}

Three comprehensive studies of ancient Near Eastern (ANE) treaties that also deal with biblical covenantal texts have been published in the last decade. ${ }^{1}$ Of course, overviews of the ANE treaty tradition are no novelty to biblical studies. ${ }^{2}$ Nevertheless, what distinguishes the three works reviewed here is their synthesis of the latest scholarship, especially with respect to political instruments from the Old Babylonian (OB) and Hittite eras. ${ }^{3}$ In particular, they are the first comprehensive studies to take fully into consideration treaties and loyalty oaths from the city-states of Mari (Tell Hariri) and Apum

\footnotetext{
${ }^{1}$ Kenneth A. Kitchen and Paul J. N. Lawrence, Treaty, Law and Covenant in the Ancient Near East 3 vols. (Wiesbaden: Harrassowitz, 2012); Amnon Altman, Political Treaties of the Ancient Near East [Hebrew], Biblical Encyclopedia Library 34 (Jerusalem: Bialik Institute, 2018); Dominique Charpin, "Tu es de mon sang». Les alliances dans le Proche-Orient Ancien (Paris: Les Belles Lettres/College de France, 2019).

${ }^{2}$ For example, George E. Mendenhall, Law and Covenant in Israel and the Ancient East (Pittsburgh: Biblical Colloquium, 1955); Dennis J. McCarthy, Treaty and Covenant: A Study in Form in the Ancient Oriental Documents and in the Old Testament $2^{\text {nd }}$ edn, AnBib 21A (Rome: Biblical Institute, 1978); Paul Kalluveettil, Declaration and Covenant: A Comprehensive Review of Covenant Formulae from the Old Testament and the Ancient Near East, AnBib 88 (Roma: Pontifico Instituto Biblico, 1982); Luciano Canfora, Mario Liverani, and Carlo Zaccagnini (eds), I Trattati nel mondo antico: forma, ideologia, funzione, Saggi di storia antica 2 (Roma: L'Erma di Bretschneider, 1990); Noel Weeks, Admonition and Curse: The Ancient Near Eastern Treaty/Covenant Form as a Problem in Inter-Cultural Relationships, JSOTSup 407 (London: T\&T Clark, 2004).

3 The entry on "Staatsvertrag (treaty)" in $\mathrm{R} l A 13$ (2011) also represents a recent state of the art survey, however it makes no attempt at synthesis. It is divided into three sections: Jesper Eidem ("A. 3-2 Jahrtausend," 3840) focuses mainly on OB materials; Simo Parpola (B. "Neuassyrisch," 4045), on the Neo-Assyrian era; and G. Wilhelm (C. "Bei den Hethitern," 45 49) on Hittite evidence.
} 
(Tell Leilan); ${ }^{4}$ they also reflect newer scholarship on Hittite diplomacy. ${ }^{5}$

While these books have implications for the study of agreements between human beings recorded in the Hebrew Scriptures, ${ }^{6}$ all three monographs raise important methodological questions regarding parallels between divine covenants with Israel and ANE texts. In part, such problems arise because the concept of "covenant" is not self-evident from the Hebrew Scriptures. ${ }^{7}$ That imprecision is compounded by the fact that identification of ANE treaty documents is not necessarily self-evident either. For example, both Hittite isḩiul and Akkadian adê can refer to texts that govern external and internal political relationships. As will become apparent, the authors surveyed in this essay have different opinions about how to distinguish inter-state treaties, ${ }^{8}$ loyalty oaths and royal decrees. The discussion below will survey each work in turn (\$\$1-3) before concluding with some summary remarks $(\$ 4)$.

4 The four treaty texts from Mari are translated in Treaty, Law and Covenant 1:211-24 (\#\#20-23). The editio princeps of five treaty texts from Tell Leilan is published in Jesper Eidem, The Royal Archives from Tell Leilan: Old Babylonian Letters and Treaties from the Lower Town Palace East (PIHANS 117; Leuven: Peeters, 2011), 346-426. In addition, six loyalty oaths from Mari have now been published. Five were translated by Jean-Marie Durand, "Précurseurs syriens aux protocoles néo-assyriens," in Marchands, diplomates et empeurers: Études sur la civilization mésopotamienne offertes à Paul Garelli, ed. Dominique Charpin and Francis Joannès (Paris: Éditions Recherches sur les Civilisations, 1991, 14-53. A sixth loyalty oath from Mari was published by Dominique Charpin, "Un Nouveau " protocole de serment» de Mari," in Opening the Tablet Box: Near Eastern Studies in Honor of Benjamin R. Foster, ed. Sarah C. Melville and Alice L. Slotsky, CHANE 42 (Leiden: Brill, 2010), 48-75. All of the texts from Mari and Apum are available online at http://www.archibab.fr.

${ }^{5}$ For the importance of recent scholarship on Hittite texts for biblical studies, see Birgit Christiansen and Elena Devecchi, "Die hethitische Vasallenverträge und die biblische Bundeskonzeption,” BN 156 (2013), 6587.

${ }^{6}$ For example, the biblical record reports agreements between states (1 Sam 11:1; 2 Sam 10:19; 1 Kgs 5:26; 2 Kgs 16:17; 17:3-4), oaths of loyalty given to a monarch by his subjects (2 Sam 5:3; $2 \mathrm{Kgs} \mathrm{11:12),} \mathrm{pacts} \mathrm{of} \mathrm{non-}$ aggression (Gen 21:27; 31:44), pledges of friendship (1 Sam 18:3; 23:18), and human marriage as a covenant (Mal 2:14).

7 See, e.g., Gary N. Knoppers, "Near Eastern Grants and the Davidic Covenant: A Parallel?” JAOS 114 (1996): 695-96; Joachim J. Krause, Die Bedingungen des Bundes, FAT 140 (Tübingen: Mohr Siebeck, 2020), 19-20.

${ }^{8}$ In this article, I prefer to use the term "inter-state" rather than "international" to designate political instruments that regulated relationships between states and their rulers in the ANE. I accept the position of Charpin (Tu es de mon sang, 17) that using the term "international" risks being somewhat anachronistic given the ways in which states at the time were organized. 


\section{TREATY, LAW AND COVENANT}

Of the books under discussion, the three-volume magnum opus of Kenneth Kitchen and Paul Lawrence is the only one to that has been subject to wide scholarly appraisal, ${ }^{9}$ including three lengthy review essays. ${ }^{10}$ Due to the amount of critical interaction with these volumes no comprehensive review of the book's contents will appear here. Rather, the focus will be to extend concerns that have been raised by previous reviewers.

Kitchen and Lawrence claim that their interest in combining ANE law collections, treaties and biblical covenants in a single work is justified because, "These three instruments are three parts of a single triptych of organized and 'organic' governance in antiquity, and they show clear features of interrelation and cross-fertilization in various epochs." ${ }^{11}$ For that reason, the first volume presents an anthology (in both transcription and translation) of nine legal collections, 64 treaties and ten biblical covenants that stretch from the famous "Vulture Stela" (25 th $c e n t . B C E)$ to the Neo-Babylonian Laws. An excursus presents a number of related documents in translation, including treaties from Tell Leilan that were not available to the authors in transcription, some Hittite documents, and a short miscellany from classical times. A second excursus lists material that was excluded due to their incomplete state of preservation or because they fall outside the authors' definition of law, treaty and covenant (e.g., Hittite royal decrees).

The second volume (Text, Notes and Chromograms) begins with brief descriptions of each text that identify their historical and geographical provenance (to the extent that these can be determined) along with notes about choices made in analyzing their literary structure and translation. A comprehensive set of indices are then provided that catalogue the stipulations these various documents contain, weights and measures, names of deities, themes of curses and blessings, and notes on legal terminology. Part 2 ends with maps and a series of colour-coded charts (chromograms). These charts present the formal elements attested in each treaty document in schematic form.

9 See, e.g., the reviews of Treaty, Law and Covenant by M. Stol, BO 70.12 (2013): 264-68; Bob Becking, NTT 67 (2013): 318-19; Reinhard Achenbach, ZABR 20 (2014): 304-306; Gary Beckman, BASOR 372 (2014): 222-24; Richard S. Hess BBR 24 (2014): 531-32; Christoph Koch, $Z A W 126$ (2014): 454-55; Pekka Pitkänen, NEA 78.2 (2015): 122-23; James K. Hoffmeier, Trinity Journal 37 (2016): 264-66.

${ }^{10}$ Ben Boeckel, "Doing Form Criticism with Slippery Genres: A Review of Treaty, Law and Covenant," HS 55 (2014), 411-30; Jacob Lauinger, "Approaching Ancient Near Eastern Treaties, Laws and Covenants," JAOS 136 (2016), 125-34; Eva Von Dassow, "Treaty, Law and Bible in Literalist Theory," Ancient Near Eastern Studies 53 (2016), 287-98.

${ }^{11}$ Kitchen and Lawrence, Treaty, Law and Covenant, 1:xxii. 
Part 3: Overall Historical Survey aims to synthesize the material in the first two volumes. One of its driving interests is to date records of biblical covenants within the larger context of the ANE legal tradition. To that end, Treaty, Law and Covenant situates the patriarchal covenants (Gen 21:22-24; 25-33; 26:26-31; and 31:44-54) in a context that must belong to the Old Babylonian period. Further, it identifies the Sinai covenants now distributed over the books of ExodusDeuteronomy and Joshua 24 as compositions that must be dated to the Late Bronze (LB) era.

There is a great deal to admire about this monumental work and the scholarship it represents. Its authors have provided a valuable resource for researchers interested in comparative work between biblical and ANE covenantal texts. Regrettably, however, the methodology underlying Treaty, Law and Covenant is flawed. Kitchen and Lawrence describe their approach to the comparative task with the claim that, "we are neither theorists nor fundamentalists (of the 'left' or the 'right') but insistently factualists." ${ }^{12}$ Nevertheless, there is considerable theorizing underlying this book that is not clearly explained but which affects the "facts" they claim to determine. Various reviewers have raised concerns about how Kitchen and Lawrence conceive the comparative task. ${ }^{13}$ For example, underlying their method and selection of materials are significant matters of form-critical theory that are not worked out. ${ }^{14}$ Moreover, their concept of "covenant" is less defined than their descriptions of "treaty" or "law code." 15

In this review, I will address two commitments of Treaty, Law and Covenant that call for comment beyond previous critiques. First, Kitchen and Lawrence claim that a metahistory of the ANE treaty tradition can be constructed to the point that Israel's major covenants with YHWH are to be dated firmly to the second millennium. ${ }^{16}$ Second, their choice of comparative materials undervalues certain classes of texts.

With respect to the first point, it is clear that treaty formularies normally located in second millennium documents appear sporadically in first millennium contexts. This is noteworthy in the treaty between Assurbanipal and the Arabs of Qedar and the treaty between Hannibal of Carthage and Philip V of Macedon. Moreover, a chronological distribution of treaty elements cannot be maintained in the cases of either Sefire or Deuteronomy.

${ }^{12}$ Kitchen and Lawrence, Treaty, Law and Covenant, 3:261.

${ }^{13}$ E.g., Charpin, Tu es de mon sang, 250-54; Lauinger, "Approaching Ancient Near Eastern Treaties," 133; Von Dassow, "Treaty, Law and Bible," 292.

${ }^{14}$ Boeckel, "Doing Form Criticism," 428-29.

15 Ibid., 419; Von Dassow, “Treaty, Law and Bible," 290.

${ }^{16}$ Kitchen and Lawrence, Treaty, Law and Covenant, 1:xx. 
As is well-known, there is a brief historical allusion made in the treaty between Assurbanipal and the Arabs of Qedar. ${ }^{17}$ While Kitchen and Lawrence would deny its status as a historical prologue in parallel to Hittite vassal treaties, Altman thinks differently. ${ }^{18} \mathrm{Nev}$ ertheless, both discussions note the unusual placement of its godlist, which recalls a convention found in $\mathrm{OB}$ treaties from Mari and Apum. In fact, the chronograms in Treaty, Law and Covenant show that the Qedar treaty contains the same elements as these OB treaties in the same order (witnesses coupled with oath, followed by stipulations). ${ }^{19}$ A similar formulary can be reconstructed in Gen 21:22-24, a parallel that belies the possibility of firmly situating this Abrahamic covenant in the second millennium. ${ }^{20}$

A similar observation can be made with respect to the Hellenistic treaty between Hannibal of Carthage and Philip V of Macedon, which is recognized by Treaty, Law and Covenant as a "chronological stray." 21 Its form, in which a preamble is followed by a god-list and then stipulations, reflects a model also found in the Middle Hittite treaty between Arnuwanda I and the people of Ismerika. ${ }^{22}$ In addition to formal parallels, there are also important contacts with the second millennium on the level of content. As Michael Barré points out, the god-list "reflects the Hittite treaties arrangement precisely," starting with supreme deities, then mentioning the protective deity and the war-deity. Moreover, the phrase "the gods of those who take the fields with us" follows the Hittite pattern. ${ }^{23}$

Distribution of treaty elements also confounds firm chronological distinctions. Two examples occur in the Iron Age texts from Sefire. In Sefire III one notes the frequent use of the repression formula ("you shall have been unfaithful to this treaty") to punctuate various stipulations. This is a compositional tactic which can be found in various Hittite treaties, but which is otherwise unattested in extant first millennium sources. ${ }^{24}$ Moreover, Sefire I C evidently con-

\footnotetext{
17 SAA 2 10, obv. 4-11.

18 Compare Kitchen and Lawrence, Treaty, Law and Covenant, 2:99-100; 3:232 and Altman, Political Treaties, 477-78.

${ }^{19}$ Kitchen and Lawrence, Treaty, Law and Covenant, 2:257 and 265.

20 William S. Morrow, "Jacob's Treaty with Laban in the Light of Ancient Near Eastern Diplomacy," in Dynamics of Early Judaean Law, ed. Sandra Jacobs, BZAW (Berlin: De Gruyter, forthcoming).

${ }^{21}$ Kitchen and Lawrence, Treaty, Law and Covenant, 3:240.

22 Cf. Kitchen and Lawrence, Treaty, Law and Covenant, 2, \#\# 54 and 105.

${ }^{23}$ Michael L. Barré, The God-List in the Treaty Between Hannibal and Philip $V$ of Macedonia: A Study in the Light of the Ancient Near Eastern Treaty Tradition (Baltimore: John Hopkins University, 1983), 101-102.

${ }^{24}$ William S. Morrow, "The Sefire Treaty Stipulations and the Mesopotamian Treaty Tradition," in The World of the Aramaeans III: Biblical, historical and cultural studies in honour of Paul-E. Dion, ed. P. M. M. Daviau. J. William Wevers and Michael Weigl, JSOTSup 326 (Sheffield: JSOT Press, 2002), 84-88.
} 
tained parallel blessings and curses - a trait usually associated with Hittite texts, ${ }^{25}$ but also attested in the epilogue of the Laws of Hammurabi (col. xlviii-li).

In other words, developments in the ANE treaty tradition that affected the biblical record cannot necessarily be traced in an orderly fashion. ${ }^{26}$ Further evidence for this claim comes from the book of Deuteronomy — ostensibly from the late second millennium according to Treaty, Law and Covenant because its form resembles one common to Hittite vassal treaties and certain ANE legal collections, including the Laws of Hammurabi. ${ }^{27}$ In making this claim, however, its authors must dismiss parallels between the "Succession Treaty of Esarhaddon" and Deuteronomy 28. ${ }^{28}$ Kitchen and Lawrence, however, overlook the fact that Deuteronomy has multiple connections with NA treaty rhetoric. Quite aside from the question of Deuteronomy 28 , there are analogies to be found in Deuteronomy $13,{ }^{29}$ as well as in chapter $29 .{ }^{30}$ Such associations situate the composition of Deuteronomy in the later Iron Age.

Another issue that requires attention is Kitchen and Lawrence's conception of texts appropriate for comparison with biblical covenants. In this respect, Kitchen and Lawrence find an overlap between law collections, inter-state treaties, and biblical covenants. ${ }^{31}$ Yet, they rule out comparison with other legal instruments including royal decrees and second millennium loyalty oaths. ${ }^{32}$ Their decision seems to be motivated by the assumption that the most important formal parallel to Israel's covenants with YHWH is the inter-state treaty, especially in the form it took in the Hittite world. Consequently, the relevance of royal decrees is underplayed and some biblical evidence is overlooked.

In fact, there are at least three facets of ANE royal decrees that relevant to biblical covenants. First, a number of decrees of the kind known as royal land grants have been applied to biblical texts. ${ }^{33} \mathrm{Sec}-$

25 Curiously, Kitchen and Lawrence (Treaty, Law and Covenant 3:220) ignore the fact that there are blessings as well as curses in Sefire I in their discussion of its contents.

${ }^{26}$ Christoph Koch, Vertrag, Treueid und Bund: Studien zur Rezeption des altorientalischen Vertragrechts im Deuteronomium and zur Ausbildung der Bundestheologie im Alten Testament (BZAW 383: Berlin: de Gruyter, 2008), $27-$ 29.

${ }^{27}$ Kitchen and Lawrence, Treaty, Law and Covenant, 3:148-55.

${ }^{28}$ Ibid., 3:231-32.

${ }^{29}$ William S. Morrow, "Have Attempts to Establish the Dependency of Deuteronomy on the Esarhaddon Succession Treaty (EST) Failed?” HeBAI 8.2 (2019), 144-6.

${ }^{30}$ Moshe Weinfeld, Deuteronomy and the Deuteronomic School (Oxford: Oxford University, 1972), 115-16.

${ }^{31}$ Kitchen and Lawrence, Treaty, Law and Covenant, 3:132-36.

${ }^{32}$ Ibid., 1:1082. Stol $(B O, 266)$ observes that their exclusion of decrees, edicts and loyalty oaths is a "grey area."

33 See, e.g., Moshe Weinfeld, "The Covenant of Grant in the Old Tes- 
ond, royal decrees gave monarchs an instrument for modifying existing relationships with subordinates in various ways. A good example of a decree that supplemented an existing treaty relationship was the one issued by the Hittite king, Mursilli II to Niqmepa of Ugarit. It determined the boundary between Ugarit and the neighbouring Hittite client kingdom of Mukish; it also altered the amount of tribute expected from Ugarit. ${ }^{34}$ Finally, royal decrees also overlap with the genre of the ANE law collection. ${ }^{35}$ Although, the law collections prefer a more impersonal form of instruction than one usually finds in treaties, ${ }^{36}$ they show a number of relationships with legal decisions issued by order of the king (S.imdat sarrim). ${ }^{37}$ In fact, both the Laws of Eshnunna ( $(58)$ and the Laws of Hammurabi $(\$ 51)$ appeal to royal edicts as sources for settling legal disputes. ${ }^{38}$

Their concentration on analogies between inter-state treaties and biblical covenants also leads Kitchen and Lawrence to overlook some relevant biblical passages. For example, no explanation is given for the omission of Genesis 17, though this text describes a mode of covenant ratification. ${ }^{39}$ Just as curious is the failure to include the loyalty oath found in Neh 10:29-40. Portions of this text are written in the first person, as one can also find in loyalty oaths from the

tament and in the Ancient Near East." JAOS 90 (1970), 184-203; Theodore E. Mullen, "The Divine Witness and the Davidic Royal Grant: Ps 89:3738," JBL 102 (1983), 207-18; Andrew E. Hill, “The Ebal Ceremony as Hebrew Land Grant? JETS 31 (1988), 399-406; as well as the critique of Weinfeld's thesis in Knoppers, "Near Eastern Grants and the Davidic Covenant," 694-96. McCarthy (Treaty and Covenant, 163) objected to comparisons between biblical covenants and ANE royal grants or decrees on the grounds that the latter were not imposed by oath. However, as Altman (Political Treaties, 329) points out, royal decrees can assume the existence of a relationship that has already been established by oath.

34 Translated in Beckman, "Edicts of Mursili II of Hatti concerning the Frontiers and Tribute of Ugarit," Hittite Diplomatic Texts, \#31A (pp. 17377); see also the discussion and translation in Altman, Political Treaties, \#44 (pp. 329-35).

35 A good example is the Middle Assyrian Palace Decrees, see Lauinger, "Approaching Ancient Near Eastern Treaties," 125-26.

36 See William S. Morrow, "A Generic Discrepancy in the Covenant Code," in Theory and Method in Biblical and Cuneiform Law: Revision, Interpolation, and Development, ed. Bernard M. Levinson, JSOTSup 181 (Sheffield: JSOT Press, 1994), 138. ANE law collections consistently use third-person syntax in formulating their provisions. The occasional use of second person references in quoted material does not undermine this observation (cf. Laws of Eshnunna \$22; Laws of Hammurabi \$192), as they are not part of the casuistic formula per se.

${ }^{37}$ Klaas R. Veenhof, "The Relation between Royal Decrees and 'Law Codes' in the Old Babylonian Period," JEOL 35/35 (1997-2000), 68-78.

38 Veenhof, "Relation between Royal Decrees and 'Law Codes'," 74.

39 Boeckel ("Doing Form Criticism," 412) notes Treaty, Law and Covenant's puzzling omission of the berrit in Genesis 17 while including 2 Samuel 7 , whose covenantal implications are only indicated in other texts. 
Bronze Age. ${ }^{40}$ Loyalty oaths typically differ from vassal treaties in the absence of elements such as the historical introduction, calling on the gods, and cursing and blessing formulas. This is due to the fact that their addressees were regarded as already bound to the monarch. ${ }^{41}$ Nehemiah 10 reflects this pattern. Here the people undertake solemnly to "enter into a curse and an oath to walk in God's law" (v. 29). Moreover, the contents of the oath make reference to behaviours that the authors of Treaty, Law and Covenant otherwise allow as covenant stipulations including a prohibition against intermarriage (v. 30), sabbatical observances (v. 31), tithes, first-fruit and firstling offerings (vv. 35-37).

The omission of Nehemiah 10 is puzzling because Kitchen and Lawrence include all of the NA adê for comparative purposes, although some are obviously internal loyalty oaths. Presumably, NA loyalty oaths were anthologized because the authors find their structure compatible with their model of the vassal treaty. But the absence of Nehemiah 10 begs the question as to what criteria ought to be employed for identifying parallels between biblical covenants and ANE texts. This concern also manifests itself in the other two books reviewed in this essay.

\section{Political Treaties of the Ancient Near East}

The late Amnon Altman's book consists of two parts: an analytical survey of the ANE treaty tradition, and an extensive collection of treaty documents introduced and translated into modern Hebrew. The first part of the book builds on previous work published in English. Chapters 1-5 expand discussions of the ANE treaty tradition that appeared previously in Altman's survey of international law; 42 Chapter 6 is a revision of an article written by Altman's chief collaborator, Ada Tagger-Cohen. ${ }^{43}$ The second part of the book contains annotations and translations of 73 political instruments, including 6 Hittite royal decrees and one Hittite royal instruction.

The first chapter deals with questions of geographic distribution, language of composition, the state of the documents, and history of scholarship. As Altman notes, around 65 treaty texts are attested from the beginnings of ANE history through to the Persian period. While neither chronological or geographical distribution is

${ }^{40}$ First person singular references appear in all of the loyalty oaths published in Durand, "Précurseurs syriens." Though rare, first person plural references appear in at least one Hittite loyalty oath, see Jared L. Miller, Royal Hittite Instructions and Related Administrative Texts, SBLWAW 31 (Atlanta: Society of Biblical Literature, 2013), 34.

${ }^{41}$ Christiansen and Devecchi, "Die hethitische Vasallenverträge," 72.

${ }^{42}$ Amnon Altman, Tracing the Earliest Recorded Concepts of International Law: The Ancient Near East (2500-330 BCE), Legal History Library 8/4 (Leiden: Brill, 2012).

43 Ada Tagger-Cohen, "Biblical covenant and Hittite ishiul reexamined," VT 61 (2011), 461-88. 
uniform, in general there appear to be two major traditions of treatymaking: Syro-Hittite and Mesopotamian. There are particular problems, however in classifying parity-treaties, which are attested in a variety of styles.

For the purposes of describing the conventions of international law operative in the ANE, Altman believes that a base for comparison can be established by privileging the Hittite evidence, which is the fullest available. He expresses pessimism about the ability to carry out the comparative task the further one moves away from the Hittite material in either chronology or geography. Here is a case, however, in which Political Treaties needs to be read in conjunction with the work of Charpin. Altman's decision to concentrate on treaty texts and decrees essentially overlooks the rich amount of information that is available about the OB treaty tradition from the correspondence preserved at Mari and related city-states. Moreover, Altman does not fully take into consideration the fact that distinctions can be made between treaties contracted in the Middle Hittite period and the Late Hittite period: Middle Hittite treaties were not as uniform in structure as those of the later era. ${ }^{44}$

The second chapter addresses questions of definition and terminology. Altman eschews the terminology of "vassal treaty," which he regards as anachronistic. He prefers the term berrit keеpiphit, "a treaty/covenant of subordination." As have others before him, Altman notes that the cultures of the ANE had no terminology that distinguished domestic contracts, international treaties, and loyalty oaths. Nevertheless, scholars are justified in making distinctions using modern categories. For this purpose, Altman carefully defines differences between parity treaties, treaties of subordination, protocols, decrees, and loyalty oaths. Among these terms, readers may be unfamiliar with his use of the term "protocol" to characterize documents meant to complete, correct, or limit existing agreements.

- Protocols required consent from both sides of the agreementunlike a royal decree, which extended certain rights to subordinates unilaterally, or edicts intended to settle disputes between citizens or subordinate powers.

The third chapter describes the various traditions of treaty making in the ANE and their historical contexts. Four features of ANE treaties receive particular attention: these include: (i) the ways in which obligations were formulated (one- vs. two-sided); (ii) use of a preamble; (iii) the duration of the agreement; and (iv) the role of the oath. One has to wait until the Hittite era for a tradition that normally recorded external political agreements in writing. In these documents, a preamble mentioning parties to the agreement is typical, though it appears sporadically in treaties before the Late Bronze Age. Unlike earlier agreements, Hittite treaties were considered binding

44 Birgit Christiansen, Schicksalbestimmende Kommunikation: Sprachliche, gesellschaftliche und religiöse Aspekte bethitischer Fluch-, Segens-, und Eidesformeln, SBOT 53 (Wiesbaden, Germany: Harrassowitz, 2012), 525. 
on subsequent generations. Finally, Altman notes a shift in the prominence given to the oath in earlier texts in favour of an insistence that the agreement is supervised by the gods. This observation conforms with Birgit Christiansen's observations that the oath does not stand in the center of the Hittite ratification ritual; more important is the mutual binding of the participants and the gods. 45 The chapter ends with observations that show that extant treaties from the Neo-Assyrian (NA) era do not all share a common structure.

The fourth chapter focuses on treaties from the Late Bronze Age. Separate sections of this chapter deal with parity treaties and subordination treaties. In dealing with Hittite subordination treaties, Altman makes some observations about the function of the historical prologue that he develops in more detail in the next chapter. In particular, he distinguishes between relationships to the subordinate that had been established in personam or in rem. The term in personam refers to a city or state that voluntarily submitted to the rule of the Hittite king, as opposed to a situation when it was captured or conquered during a war (in rem).

Biblical scholars will probably find the fifth and sixth chapters of this book the most informative. Chapter Five discusses the legal implications of the historical prologue of Hittite treaties. Effectively a digest of Altman's earlier work on this subject, his chapter highlights a number of legal functions that the historical prologue played. ${ }^{46}$ In this respect, his work could be profitably used in investigations about the legal functions of historical prologues in biblical texts, such as Deuteronomy 1-3.

A key interest of the historical prologues was to forestall objections that might lead to breaking the treaty on the basis of claims that deny its force or the authenticity of its documentation. For this purpose, Altman has a useful discussion of parallels between interstate treaties and private contracts, in which individuals sold themselves into servitude. In both cases, there is emphasis on the fact that it was the weaker side that initiated the transaction, a description of the circumstances that led to the transaction, and an indication of the compensation the weaker side received. These elements were designed to prevent the weaker party from claiming that the transaction was illegal because its was made without consent.

As noted, the sixth chapter was contributed by Tagger-Cohen. Although it rehearses arguments of Tagger-Cohen's earlier article, it is also shows some distinctive developments. This appears with respect to her treatment of the covenant ratification narrative in Joshua 24. Previously, Tagger-Cohen compared Joshua 24 to contracts of land conveyance from the Neo-Babylonian period and the Aramaic

\footnotetext{
${ }^{45}$ Christiansen, Schicksalbestimmende Kommunikation, 174.

46 Amnon Altman, The Historical Prologue of the Hittite V assal Treaties: An Inquiry Into the Concepts of Hittite Interstate Law (Ramat Gan: Bar Ilan University, 2004).
} 
archives from Elephantine. ${ }^{47}$ This essay received only slight mention in her 2011 essay; 48 however, it is not cited at all in her contribution to Altman's book. It appears, therefore, that Tagger-Cohen's search for parallels to Joshua 24 has become increasingly focused on the genre of Hittite loyalty oaths sometimes called "royal instructions" or Dienstanweisungen.

She observes that the semantic range of the Hittite lexeme ishiul has a similar flexibility to the biblical term bèrit and NA adê. So, why compare the Hittite ish hiul known as "royal instructions" to biblical covenants between Israel and YHWH, rather than inter-state subordination treaties? According to Tagger-Cohen, the Sinai covenant and the narrative in Joshua represent two different traditions about Israel's first covenant with its God. They reflect the idea that the land belongs to the deity and its management is bestowed on Yhwh's servants under certain conditions. An analogy with the genre of Hittite instructions suggests itself because the stipulations of the covenant include instructions about how the divine king's servants are to carry out their tasks. ${ }^{49}$ For that reason, the collection of documents in the second section of the book contains a translation of the wellknown "Instructions to Temple Servants." ${ }_{50}$

Overall, Altman's work raises questions about the span of material that needs to be considered in a discussion of biblical covenants. Altman shows that it is difficult to maintain a sharp distinction between treaty documents and other instruments used to regulate inter-state relations (i.e., royal decrees). His book is also informative because his genre identifications are not always in agreement with other scholars. In addition, there is a lack of integration between his work and his major collaborator, Tagger-Cohen that is instructive for biblical scholarship.

One of the contributions that Altman makes is to emphasize the fact that treaty relationships were regulated by a variety of political instruments in the ANE. In this respect, it is informative to compare the lists of Hittite treaty texts in Political Treaties with the recent work by Elena Devecchi on defining the extent of the Hittite treaty corpus. ${ }^{51}$ It overlaps with Altman's list significantly, but not com-

47 Ada Tagger-Cohen, "The Covenant as Contract: Joshua 24 and the Legal Aramaic Texts from Elephantine," ZABR 11 (2005), 27-50.

48 Tagger-Cohen, "Biblical covenant and Hittite isḩül," 485, n. 93.

49 This observation was anticipated by Moshe Weinfeld, "The Origin of the Apodictic Law: An Overlooked Source," VT 23 (1973), 63-75; see also William S. Morrow, "Ancient Near Eastern Treaties and Biblical Law" in The Oxford Handbook of Biblical Law, ed. Pamela Barmash (New York: Oxford University, 2019), 325.

50 Altman, Political Treaties, 462-74. For the latest English translation, see Miller, Royal Hittite Instructions, \#20 (pp. 244-65).

51 Elena Devecchi (["Re-]defining the Corpus of the Hittite Treaties," ZABR 19 [2013], 95-96) lists 41 treaties or excepts. Virtually the same list appears organized geographically in her book, Trattati internazionali ittiti (Brescia: Paideia Editrice, 2015); however, there she construes CTH 42 as 
pletely. In particular, Altman includes a number of royal decrees that Devechhi does not regard as treaties per se. To be sure, the interests of these two scholars are slightly different. Devecchi points to an imprecision regarding the definition of treaty in Hittite usage that goes back to the pioneering work of Viktor Korošec. ${ }^{52}$ She resolves that imprecision by defining a "treaty" as, "An 'obligation and oath' text with the function of defining and regulating the relationships between the Hittite kingdom and political entities located outside the borders of the Hittite heartland." Such texts are to be distinguished from edicts, which are official orders or proclamations and internal state administrative instruments, such as royal instructions..$^{53}$ Altman, however, is interested more generally in the practices of ANE international law and justifies his inclusion of a number of royal decrees and inter-state protocols on the assumption that they provide further definition of relationships already fixed by treaty.

With respect to what documents ought to be called "treaties," comparison between scholars is informative as it communicates the extent to which experts in the field can have varying opinions about the material they are surveying. A number of examples can illustrate this situation. The earliest treaty-document extant is the "Vulture Stele" of Eannatum. But is it actually a treaty? This question is answered in the affirmative by Kitchen and Lawrence, who regard its historical prologue as a legal justification for the conflict and its resolution in favour of Eannatum. ${ }^{54}$ On the other hand, Altman identifies the Vulture Stele as a building inscription and not a treaty per se; he leaves it open whether the historical prologue was meant as royal propaganda or as legal justification for the war. ${ }^{55}$ While Kitchen and Lawrence identify the agreement between the OB cities of Shadlash and Nerebtum as a "civic treaty," 56 Altman regards the absence of a preamble and curses as indicative of its status a "protocol." As he sees it, the document assumes a previous peace treaty and means to address certain issues that the initial agreement left open. ${ }^{57}$

A more important example that raises questions about scholarly categories affects the interpretation of the agreement called AlT 456 discovered in the OB city-state of Alalakh. According to Kitchen

a single treaty document, although it cites an earlier treaty between Šuppiluliuma I with Mariya and the men of Hayaša as well as the treaty between Suppiluliuma I and Huqqana of Hayaša. In addition, the citation of a treaty in the so-called "Indictment of Mattuwatta" (CTH 146) and the sworn statement of Kuruntiya of Tarbuntašša (CTH 106.B.2) are not given the status of separate treaty documents.

${ }^{52}$ Viktor Korošec, Hethitische Staatsverträge: Ein Beitrag zu ibrer juristischen Wertung, Leipziger rechtswissenschaftliche Studien 60 (Leipzig, Germany: Theodor Weicher, 1931).

${ }^{53}$ Devecchi, "Corpus of the Hittite Treaties," 89-90.

${ }^{54}$ Kitchen and Lawrence, Treaty, Law and Covenant, 3:4-5.

55 Altman, Political Treaties, 136-37.

${ }^{56}$ Kitchen and Lawrence, Treaty, Law and Covenant, 3:63-64.

57 Altman, Political Treaties, 167-68. 
and Lawrence, AlT 456 is a "gift of lands" from the king of Aleppo to his subordinate counterpart in Alalakh. It differs in a number of ways from $\mathrm{OB}$ inter-state treaties of the same time period: its lengthy historical resume does not come in the expected position, there is no curse section save one attached to the overlord, and the witnesses to the document are human beings not gods. Nevertheless, Kitchen and Lawrence opt for identifying AlT 456 as a treaty, as does Altman on the basis of demand for loyalty to the king of Yamhad and the oath taken by both sides. ${ }^{58}$

Unfortunately, Altman does not take into account the critique of previous scholarship on AlT 456 by Jacob Lauinger. Despite its superficial resemblances to a treaty, this text possesses a number of similarities with contemporary contracts for the acquisition of immovable property. As Lauinger notes, four elements occur in the same order in AlT456 and comparable contracts: it opens similarly, it contains an oath by the seller/donor not to reclaim the property, a restriction on whom the property may be passed on or sold to, and human (not divine) witnesses. On balance, therefore, AlT 456 is not a treaty. ${ }^{59}$ Nevertheless, it has significant implications for doing comparative work between biblical covenants and ANE parallels. It shows that generic boundaries between ANE legal traditions can be somewhat fluid and identification of appropriate documents for comparison is not always straightforward.

This observation touches on the fact that it is only Tagger-Cohen who really addresses correspondences between biblical covenantal texts and the Hittite world in Altman's volume. Although his book contains a translation of the well-known text, "Instructions for Temple Servants," in general, the Hittite royal instruction genre is not surveyed in Political Treaties. There are obvious reasons for this, as the book is focused on inter-state treaties in the ANE. Nevertheless, this omission underscores both the importance of Tagger-Cohen's contribution and the degree to which her observations remain un-integrated in the rest of Altman's oeuvre. Not only does the absence of Tagger-Cohen's perspective elsewhere in the book make for a certain amount of unevenness in its presentation of the treaty-text tradition, it also raises important questions about what texts biblical scholars ought to examine for comparative purposes. This is relevant to the analysis of biblical texts, because (as a number of scholars have remarked) the analogy between Israel's covenants with YHWH and ANE vassal treaties is by no means complete. ${ }^{60}$

\footnotetext{
${ }^{58}$ Kitchen and Lawrence, Treaty, Law and Covenant, 3:68; Altman, Political Treaties, 213.

${ }^{59}$ Jacob Lauinger, Following the Man of Yambad: Settlement and Territory at Old Babylonian Alalah, CHANE 75 (Leiden: Brill, 2015), 142-52.

${ }^{60}$ See, e.g., McCarthy, Treaty and Covenant, 297; Ralf Rothenbusch, Die kasuistische Rechtssammlung im 'Bundesbuch' (Ex 21,2-11.18-22,16) und ibr literarischer Kontext im Licht altorientalischer Parallelen, AOAT 259 (Münster: Ugarit-Verlag, 2000), 571; Weeks, Admonition and Curse, 151-56.
} 


\section{TU ES DE MON SANG. ${ }^{61}$}

Dominique Charpin eschews attempts to describe the ANE treaty genre by reliance on schemes of periodization, preferring a thematic approach. He observes that parallels to a specific treaty trait can be found in various time periods - a difficulty that he notes Altman ran into in his attempt to discuss the ANE treaty tradition by chronological eras. ${ }^{6}$

The first chapter reviews the major discoveries that have affected scholarship on ANE treaties. Beginning with the Tell Amarna letters, there are brief surveys of the archives of the Hittite empire, Ugarit, NA treaties and loyalty oaths, texts from Mari and upper Mesopotamian, and Ebla. One of the aims of this chapter is to challenge the priority that has often been accorded to the Tell Amarna letters and the Hittite archives by highlighting the richness of documentation from the OB period.

The second chapter addresses the way in which alliances were concluded in the ANE. Paradoxically, while the greatest number of written treaty documents come from the LB period, information about the manner in which covenants were ratified is much more abundant in OB texts. For this reason, a substantial portion of the chapter is given over to the material from that era. In the process, Charpin defends his thesis (against Jesper Eidem) that there were separate procedures for concluding pacts between monarchs depending on whether the negotiations were held face to face or not. Ratification by "killing an ass (or donkey foal)" only took place when the monarchs involved met face to face. ${ }^{63}$ Written treaty proposals that involved the rite of "touching the throat" were required when the royal parties did not meet but negotiated their agreement through emissaries and messengers. While it is clear that the act of the killing the ass symbolized a self-curse invoked by the ratifying parties in case of breach of agreement, interpretation of the gesture of touching the throat may be ambiguous. There is evidence that this gesture involved touching the throat with the blood of the other monarch involved in concluding the pact. This apparently involved bringing a vial of blood (preserved in oil so it would not coagulate?) for the ceremony of touching the throat. This too may have been a ceremony of self-cursing; however, it is possible that the gesture was

${ }^{61}$ Also reviewed by Jean-Georges Heintz in Hokmah 116 (2019), 133 45; Marc Van de Mieroop, JAOS 141 (2021): 702-4; Michael Jursa, VT 71 (2021): 298-300.

${ }^{62}$ Charpin, Tu es de mon sang, 19.

${ }^{63}$ Ibid., 48-64; cf. Eidem, Royal Arcbives from Tell Leilan, 312-13. I am not satisfied, however, that Charpin has fairly answered Eidem's suggestion (Royal Archives from Tell Leilan, 321-24) that the Tell Leilan evidence indicates written treaty texts might have been prepared even when the partners were not negotiating at a distance. 
made to communicate that a bond of kingship, metaphorically of "consanguinity," had been made. ${ }^{64}$

The third chapter treats procedures for putting treaties in writing, materials used to produce and preserve them (clay, metal and stone), and how they were displayed and archived. Shifts in the validity of treaties to encompass future generations and the use of precious metals to preserve them (although there is evidence for a silverplated treaty text from Ebla) signify a change in the status of written treaty texts. The chapter ends by calling into the question the widespread opinion that the copies of the Esarhaddon Succession Treaty (EST) found in the ruins of the Nabû temple at Nimrud were deliberately destroyed by the invading Medes. A revised evaluation of the temple's stratigraphy suggests that they were suspended above a throne made of wood and ivory. In the fire, they fell down and broke into pieces before the temple walls collapsed on top of them, sealing them in.

Chapter Four deals with the overall structure of treaties and their typical contents. For this purpose, it begins with a survey of four temporal groupings: the third millennium, the OB period, the second half of the second millennium and the NA era. The rest of the chapter is given over to a review of treaty stipulations with respect to political concerns, military aid, juridical and commercial matters. In terms of structure, it is difficult to find commonalities of organization among the agreements from Ebla; in particular, they do not consistently use a preamble that identifies the parties involved. While there are a couple of exceptions, OB and Old-Assyrian treaty texts generally share a common structure, which is reflected in the "large-tablet" format: a list of gods (followed by the name of the king who swears by them), then a list of stipulations, ending with curses. Elsewhere, Charpin notes that, in contrast with Hittite practice, loyalty oaths from Mari follow the same formulation as subordination treaties. ${ }^{65}$

In the Hittite treaty tradition, one generally finds the god-list displaced toward the end of the agreement before concluding curses and blessings. For the first time, it becomes possible to formally distinguish treaties between equals and non-equals. It remains an open question, however, whether the Hittites adapted a treaty-making tradition they inherited from the OB period or had a separate tradition. With respect to the NA era, Charpin notes the dispute over the derivation of the word adê. He favours the view of Durant now followed by Lauinger that its antecedent is not to be found in Aramaic, but in the Akkadian word adûm, which signifies "a duty" or "a task to be accomplished." 66 A difficulty with this derivation, however, is that it

${ }^{64}$ Charpin, Tu es de mon sang, 76-78.

65 Ibid., 135.

${ }^{66}$ See Durand, "Précurseurs syriens," 70, n. 167; Jacob Lauinger, "The Neo-Assyrian adê: Treaty, Oath, or Something Else," ZABR 19 (2013), 15. 
does not explain the origins of Hebrew 'édutt, which also can mean "covenant" and which is cognate with Aramaic 'dyn.

A fifth chapter is devoted to the concept of evoking divine guarantors for political agreements. Here Tu es de mon sang surveys the nature of the gods who were invoked as witnesses and guarantors of treaty agreements, the various types of curses, and the role played by war as an expression of divine punishment for treaty breach. As noted above, a strength of Charpin's presentation is his appeal to the rich correspondence from the Mari era to illustrate his points. Changes in the use of curses can be discerned in the history of ANE political agreements. For example, the increased importance of written texts in the second half of the second millennium is underscored by the inclusion, for the first time, of curses that not only cover the performance of treaty stipulations but which also protect the integrity of the text itself. In this regard, Charpin is critical of the classification of curses in the EST, as it appears in SAA 2. In his opinion, all of the curses in $\iint 35-56$ (the "Standard Curse Section") are devoted to preserving the integrity of the treaty tablet itself. The second set of curses in $\$ \$ 58-106$ (the "Ceremonial Curse Section") were intended to protect the integrity of the oath.

The sixth chapter deals with subject matter that the other two works reviewed in this essay do not discuss in any detail: exchanges of gifts and dynastic marriages as a means for concluding and solidifying treaty relationships. This discussion complements earlier observations that Charpin makes about the relationship between treaties and marriages, especially in the OB period. ${ }^{67}$ Not only is the same metaphor used ("knotting the fringe"), but both relationships underscore the idea that treaties between kings in that time period constituted the creation of personal relationships between the parties involved. Material related to gift exchange focuses mainly on testimony from the second millennium. With respect to dynastic marriages, however, there is a survey of sources from the third millennium, the OB, Late Bronze and NA eras. The survey ends with a discussion of the status of these women in the courts into which they were married.

Charpin's seventh and final chapter will be of most immediate interest to the majority of biblical scholars as he surveys connections between ANE treaty traditions and biblical covenants. In this regard, he distinguishes three types of biblical covenants: a covenant of obligation for which the legal model is constituted by ANE treaties (represented by the covenant at Sinai); a covenant of promise concerning figures such as Abraham and David; and a covenant of marriage (e.g., Hosea and Jeremiah).

A review of past scholarship establishes the legitimacy of finding parallels in both Hittite and NA sources; however, there is no necessity to start with evidence from the second half of the second millennium. Charpin suggests that there are four items where com-

${ }^{67}$ Charpin, Tu es de mon sang, 94-95. 
parison with the $\mathrm{OB}$ treaty-texts from Mari and Tell Leilan is profitable: the sacrifice of the donkey foal; the etymology of the Hebrew term berrit, the obligation for sincerity, and the symbolism of blood. With respect to the slaughtering of the donkey foal, he notes an analogue in Sefire IA:39-40 to the rites found in Mari (cf. Gen 15:9 and Jer 34:18). So far as derivation and meaning of the term berrit is concerned, Charpin supports the thesis of Jean-Georges Heinz, who has revived the claim that this vocable is etymologically and semantically connected to the Akkadian preposition birit, meaning "between." 68 Following Heinz, he also notes the close correspondence between the biblical phrase bekol lébabékea and the OB expression ina libbim gamrim. ${ }^{69}$ Examples can be found in documents from both Mari and Tell Leilan. Finally, Charpin notes that the element of blood has a symbolic importance in both $\mathrm{OB}$ and biblical treaty ratification ceremonies that is not attested in other ANE treaty traditions. A ceremony such as the one reported in Exod 24:4-8 shows that the blood was poured over both parties (the altar representing YHWH) as a gesture of auto-malediction.

As with the other two books reviewed here, Charpin's work reveals difficulties in determining what documents ought to be considered as treaties. According to him, the term "treaty," strictly speaking, should not be used for the Amorite period. All that have been preserved are proposals (protocoles) for solemn oaths among kings. Note that Charpin uses the French term in a sense diametrically opposed to that of Altman. For Charpin a protocole is a proposal for making a treaty, not an extension of a pre-existing relationship.

Negotiations at a distance involved an initial exchange of proposals for an alliance by means of the "small tablet." Once these proposals were accepted, there ensued an exchange of "large tablets" with more detailed lists of stipulations. Yet, even these were, in the final analysis, proposals and one does not know whether they were accepted as written, revised or refused in the actual act of oath-taking, which was performed orally. ${ }^{70}$

But, how far should this skepticism be entertained? Charpin is correct, of course, to claim that the large tablets from the OB period contain provisions that could have been changed at the last moment. Moreover, from a methodological perspective, he is on firm ground to label textual forms on the basis of what is preserved, not what may have occurred if the agreements were ratified. But I do not believe that his reasoning prevents one from referring to the $\mathrm{OB}$ ma-

${ }^{68}$ Jean-Georges Heintz, "Nouveaux traités d'époque babylonienne ancienne et formules d'alliance de la Bible hébraïque: Remarques préliminaires," Prophétisme et Alliance: Des archive royales de Mari à la Bible hébräque, OBO 271 (Fribourg/Göttingen: Academic Press/Vandenhoeck \& Ruprecht, 2015), 296-300.

${ }^{69}$ Heintz, " "Dans la plenitude du Coeur». À propos d'une formule d'alliance à Mari, en Assyrie et dans la Bible," Prophétisme et Alliance, 323-34.

${ }^{70}$ Charpin, Tu es de mon sang, 101-102. 
terial from Mari and Tell Leilan as "treaty texts." Arguably only two Hittite treaties in their final ratified form have been recovered: the bronze tablet of the alliance between Tudbaliya IV and Karunta and the sealed tablet between Tahurwaili and Eheya. Most of the Hittite treaties discovered only exist as copies or drafts that may not have agreed completely with the final treaty documents. ${ }^{71}$ Moreover, Charpin has to explain away an indication that at least one large tablet was intended to be a treaty document. LT 3 from Tell Leilan ends with a colophon which may indicate the date on which the stipulations it contains were ratified by oath. He suggests that the colophon may have been intended as an anticipation of the ceremony rather than a report that it had taken place. ${ }^{72}$ Surely, this same reservation can be registered about a number of Hittite treaty documents, which may be drafts of agreements rather than final records? To be fair to Charpin, his concern registers an important observation. Evidently, the status of written treaty texts did undergo a change in the second half of the second millennium. Especially in Hittite culture, the written text received a status, even a sort of sacralization that treaty documents did not receive in the $\mathrm{OB}$ period. Nevertheless, aside from various references to treaty stipulations and oaths in correspondence, the evidence from Mari and Tell Leilan constitutes primary evidence of what the form and contents of $\mathrm{OB}$ treaties would have looked like. For this reason, it seems appropriate to continue to refer to them as treaty texts, even if it is correct to entertain some doubt as to whether all the provisions that they contain were finally accepted by the treaty partners involved.

A second reservation about Charpin's work arises from the fact that, although he acknowledges that covenantal paradigms in the Bible can apply to different relationships (including friendship and internal loyalties), this is not an interest he pursues in detail. The thematic parallels he underscores are usually connected to inter-state treaties. But this raises the question as to how far these analogies can be pursued in the description of biblical covenants. Other kinds of texts including royal decrees and the Hittite instruction genre are essentially overlooked.

\section{SUMMARY REMARKS}

All three works touch on issues that have been raised throughout the history of biblical scholarship's engagement with ANE treaty texts. These concern the premises of comparative methodology, the selection of texts for comparison, and the possibility of establishing a metahistory of ANE treaty types. ${ }^{73}$ Taken together, they demonstrate that biblical scholars should bear in mind both the flexibility of treaty 68.

${ }^{71}$ Christiansen and Devecchi, "Die hethitische Vasallenverträge," 67-

${ }^{72}$ Charpin, Tu es de mon sang, 132-33.

73 See the overviews in Weeks, Admonition and Curse, 134-42; Morrow, "Ancient Near Eastern Treaties and Biblical Law." 
forms and their interrelationships with loyalty oaths and royal decrees when making comparisons to Israel's covenants with YHWH.

With respect to treaty formularies, there is a sharp difference between the approaches of Kitchen and Lawrence, and Charpin. While the former believe that meaningful distinctions can be made between treaties types through time, the later has opted for a thematic approach. Presumably, Charpin would agree with Dennis McCarthy that, "In spite of variations in different times and places, variations even of some importance, there is a fundamental unity in the treaties." 74 Altman represents a mediating position. Basing himself on the Hittite evidence (especially from the $14^{\text {th }}-13^{\text {th }}$ centuries), he suggests that the comparative task becomes more difficult the further one moves away from the Hittite material in either chronology or geography.

Obviously, each approach has ramifications for comparison between biblical covenants and the ANE inter-state treaty tradition. Yet, one must conclude that the dating of biblical covenants cannot be reliably carried out with reference to form alone. In fact, a number of features that characterize a particular era occur occasionally in different chronological contexts. Within the second millennium, for example, although the Hittite treaty tradition generally puts the god-list towards the end of the document, there are at least two cases in which the god-list immediately follows the preamble, reflecting an organization common in earlier OB treaty texts. ${ }^{75} \mathrm{It}$ is also clear that a number of treaty elements normally found in the second millennium sporadically appear in Iron Age texts. This is noteworthy in the treaty between Assurbanipal and Arabs of Qedar, the Aramaic stelas from Sefire, and the agreement between Hannibal of Carthage and Philip V of Macedon.

An informative parallel to this situation appears with respect to the evidence for debt release. As Charpin observes, although the data are found mainly in the $\mathrm{OB}$ period (one thinks of the famous decree of Ammi-șaduqu), recent research has shown that the custom continued through the second millennium into the NA era. In other words, at the moment, testimony to debt release in the ANE is quite disjointed in terms of temporal connections. So also with the ANE treaty tradition: one must situate variant uses of these political instruments within "la longue durée." 76

Such conclusions will not come as surprise to many biblical scholars. However, there is another dimension to the ANE treaty tradition that bears attention. That is, inter-state treaties belong to a larger constellation of political instruments that created and cemented political relationships through oath-taking ceremonies. In

\footnotetext{
${ }^{74}$ McCarthy, Treaty and Covenant, 122.

75 See the treaty between Arnuwanda I and the people of Ismerika in Beckman, Hittite Diplomatic Texts, \$1A; and “Tudhaliya I?'s Instructions and Oath Imposition for All the Men” in Miller, Royal Hittite Instructions, $₫ 10$.

${ }^{76}$ Charpin, Tu es de mon sang, 363-64.
} 
this respect, all three books reviewed here display a common weakness. From the perspective of Israel's covenants with YHWH, they tend to focus the scholarly gaze on inter-state treaties. To be fair, this is not true of the contribution made by Tagger-Cohen to Altman's book. Nevertheless, the fact that her essay is not well integrated into his survey of ANE political treaties underscores the problem.

Of course, the importance of contractual relationships in the cultures of the ANE has long been noted. From that perspective, the difficulty that scholars have had in determining the form of AlT 456 is illustrative. A number of scholars have classified this contract from Alalakh as a treaty. ${ }^{77}$ While Lauinger has proven that AlT 456 is best categorized as a land conveyance, its apparent overlap with the interstate treaty form shows that ANE rulers relied on a number of political instruments secured by oath. For example, the organization of borders and political boundaries also appears occasionally in interstate treaties and in royal decrees. ${ }^{78}$

Given this degree of complexity, it is worth considering interstate treaties as a species of a broader genus of ANE "oath-texts" used for political purposes..$^{79} \mathrm{It}$ is not simply the case that there were different forms of treaties in the ANE, nor that these various forms cannot be reliably traced through time. Comparison is made more difficult with the recognition that treaties themselves have to be connected to a larger constellation of political discourse. One finds, e.g., intersections between the forms of loyalty oaths and inter-state treaties in both the $\mathrm{OB}$ and NA periods. Moreover, political relationships established by oath ceremonies were not regulated simply by one-time documents. These relationships could be modified by royal decrees, which assumed a prior relationship between sovereign and subject that had been established by oath. Indeed, some decrees used elements common to treaties such as historical preambles and divine curses. ${ }^{80}$

These sorts of combinations are informative for scholars who wish to find comparisons between the forms of biblical covenants and ANE political agreements. For example, despite the fact that she now analyzes Joshua 24 by appealing to the royal instruction genre, Tagger-Cohen continues to recognize its relationship with contracts

${ }^{77}$ Lauinger, Following the Man of Yambad, 142.

78 Among the Hittites, see e.g., the "Treaty between Muwattalli II of Hatti and Talmi-Sharrumma of Aleppo" (Beckman, Hittite Diplomatic Texts, \#14) and the "Edict of Mursuli II of Hatti concerning the Frontiers of Ugarit" (Beckman, Hittite Diplomatic Texts, \#31A). In the NA context, cf. Esarhaddons' Treaty with Tyre (SAA 2 5, rev. 18'-21') and “Adad-nerari Adds the Land of Hindaru to the Territory of Rașappa” (SAA 12 85).

${ }^{79}$ See Rothenbusch, Bundesbuch, 525.

80 See, e.g., "Edict of Mursili II of Hatti concerning the Frontiers of Ugarit" in Gary Beckman, Hittite Diplomatic Texts $2^{\text {nd }}$ edn (SBLWAW 7: Atlanta: Scholars, 1999), \$31A (historical preamble and curses); “Adad-nerari Adds the Land of Hindaru to the Territory of Rașappa," SAA 1285 (preamble and curses). 
of land conveyance. Moreover, the contents of the covenants reported in Exodus 19-24 and Deuteronomy 12-25 resemble the concerns of royal instructions, although the way that they are framed has frequently reminded scholars of vassal treaties. ${ }^{81}$ Nor can one ignore the possible parallels with royal decrees. Here one is reminded of incidents in the Torah that required additional rulings after the initial relationship between Israel and YHWH had been established (e.g., Lev 24:10-23; Num 9:6-14; 15:32-36; 27:1-11; 36:1-9).

The situation is rendered more complex by two additional factors. First, it is worth noting that what are actually found in the Hebrew Scriptures are reports of covenant-making, not copies of treaty texts as one finds in the archives of ANE states. To what degree have the interests of their narrative frames affected the presentation of the covenants themselves? Charpin's hesitation about calling $\mathrm{OB}$ large tablets "treaties" in the strict sense of the word is informative in this regard. The fact that most ANE treaty texts are either drafts or copies is significant. This indicates a certain flexibility in the fixing of their final form which may have been exploited for the purposes of biblical narrative.

Second, for all their legal force, ${ }^{82}$ biblical covenants with the deity also operate on the level of metaphor. ${ }^{83}$ That is, they function to some extent by way of analogies, ones which were not - and indeed could not-be worked through exactly. Most obviously, e.g., the divine sovereign Yahweh not only imposes the treaty or makes a decree, he is also the divine witness that sanctions the agreement. Therefore, one ought not to be surprised by some degree of plasticity when ANE oath-text traditions were applied to ancient Israel's relationship with its God.

In conclusion, each has of the works reviewed here has its own strengths. Treaty, Law and Covenant contains the most extensive collection of ANE treaty texts in both translation and transcription. While Kitchen and Lawrence acknowledge that their transcriptions are not intended to replace existing standard editions of these texts, ${ }^{84}$ their compendious anthology provides a useful point of reference for biblical scholarship. The virtue of Altman's book is in describing the logic and instruments of inter-state Hittite diplomacy, while Charpin provides a robust portrayal of the relevant political documentation from Mari and related OB contexts. Taken together they present state of the art descriptions of the ANE treaty tradition, which studies of ancient Israel's covenantal traditions would do well to take fully into account.

\footnotetext{
${ }^{81}$ Morrow, “Ancient Near Eastern Treaties,” 325.

82 Tagger-Cohen in Altman, Political Treaties, 125.

${ }^{83}$ McCarthy, Treaty and Covenant, 297.

${ }^{84}$ Kitchen and Lawrence, Treaty, Law and Covenant, 1:xxii. For corrections to their transcriptions, see Stol, BO, 267-66; and Von Dassow, "Treaty, Law and Bible," 284-85.
} 